\title{
MicroRNAs in gastric cancer: from bench to bedside
}

\author{
Minireview
}

M. L. HÜ, S. W. XIONG*, S. X. ZHU, X. X. XUE, X. D. ZHOU*

Department of Gastroenterology, First Affiliated Hospital of Nanchang University, Nanchang, Jiangxi, China

${ }^{*}$ Correspondence: $y f y z x d @ 163 . c o m$

${ }^{*}$ Contributed equally to this work.

Received July 3, 2018 / Accepted August 29, 2018

\begin{abstract}
Gastric carcinogenesis results from complex interactions between host and environmental and bacterial factors, and this leads to genetic and epigenetic deregulation of oncogenic and tumor-suppressive genes. MicroRNAs (miRNAs) are a class of small noncoding RNAs which regulate almost $30 \%$ of human genes post transcriptionally and they are crucial in the initiation and progression of various diseases; especially malignancies. Accumulated evidence documents changes in gene sequences and epigenetic modifications. These then lead to abnormal miRNA expression in gastric cancer (GC) and also to deregulated miRNAs which act as oncogenes or tumor suppressors by regulating related target genes and contributing to malignant phenotypes. This altered miRNA expression in body fluids could well provide a novel biomarker for GC patient diagnosis and prognosis. MiRNAs present a promising target for GC treatment, and more tempting, for eradication of gastric cancer stem cells. This latter sub-group of tumor cells is thought to initiate and maintain GC development. Herein, we review the aberrant expression of miRNA expression and the underlying mechanisms and consequential effects of miRNA de-regulation. This identifies the responsible gastric cancer target genes, and highlights potential clinical applications.
\end{abstract}

Key words: gastric cancer, microRNAs, expression dysregulation, therapeutic target

Gastric cancer (GC) is the fourth most common cancer and the second leading cause of cancer-related death worldwide. It is especially common in Asia, Latin America, and Central and Eastern Europe and it constitutes a major burden of disability-adjusted life-years [1,2]. The pathogenesis of GC is a complex multi-step process with interaction between host and environmental and bacterial factors, wherein Helicobacter pylori (H pylori) infection is a well-documented high-risk factor $[3,4]$.

While gastrectomy is the principal treatment for patients with early-stage GC, the absence of specific symptoms in the early-stage renders most GC patients diagnosed at non-surgical stages. Systemic chemotherapy is then the major treatment option for these patients, but resistance makes treatment ineffective [5]. The current prognosis for advanced stage patients therefore remains very poor, with advanced GC patient median survival less than 12 months [6]. Investigating novel biomarkers for early diagnosis and other effective therapies based on better understanding of the mechanisms involved in gastric carcinogenesis and drugresistance is urgently required to improve patient outcome.

MicroRNAs (miRNAs) are endogenous small non-coding RNAs (ncRNAs) with approximately 18-25 nucleotides. The biogenesis of miRNAs has been identified in excellent reviews $[7,8]$, with miRNAs functioning by combining the 3 'untranslated region (UTR) of the messenger RNAs (mRNAs) of their cognate target genes. This leads to silenced expression by cleaving the mRNA molecules or inhibiting their translation [9]. Thus, approximately 30\% of human genes are modulated by miRNAs which mediate their regulation in physiological processes such as differentiation, proliferation, migration and apoptosis [10]. Because more than 50\% miRNAs are located in cancer-associated genomic regions or fragile sites, miRNA genetic alteration is considered to participate in tumorigenesis, and this has been confirmed in multiple cancers; including GC $[11,12]$. De-regulated 
miRNAs contribute to malignant GC phenotypes, including tumor growth, angiogenesis, metastasis and drug-resistance by regulating critical cellular processes as tumor suppressors or oncogenes $[5,13,14]$.

Herein, we discuss aberrant miRNA expression and resultant effects, and investigate the targets genes in gastric oncogenesis and the mechanisms underlying miRNA de-regulation. We then present the clinical application of miRNAs as novel biomarkers for diagnosis and prognosis based on their role in GC and also susceptibility prediction for these patients. The potential roles of miRNAs as therapeutic targets for GC, especially in modifying chemo-resistance and cancer stem cell (CSC) treatment, are then addressed and we introduce the general role of long non-coding RNAs (lncRNAs) in gastric cancer.

\section{Expression and function of miRNAs in GC}

Accumulated evidence documents the differential expression of specific miRNAs in GC cell lines and tumor tissues. Due to the extensive regulatory function of miRNAs in gene expression, the de-regulated miRNAs cause oncogenic activity in almost all tumorigenesis and progression; especially cell proliferation, migration, invasion and apoptosis. Oncogenic miRNAs facilitate GC tumor development with their aberrantly high expression, and silenced or lost expression of tumor-suppressive miRNAs contribute to the oncogenetic effect. Tables 1 and 2 herein summarize miRNA de-regulation and the implicated carcinogenic processes.

Tsukamoto et al. investigated the miRNA expression profiles of 22 surgically resected GC tissues and identified 39 miRNAs with different expression in tumor and non-neoplastic tissues. Of these, 6 miRNAs had comparatively lower expression in GC and the remaining 33 were up-regulated [15]. MiR-28 is a particular contributor to GC cell proliferation and invasion and it is up-regulated in $31 \mathrm{GC}$ tissues compared to matched adjacent normal gastric tissues $(p<0.05)$. This higher expression is also observed in a series of GC cell lines compared to controls [16]. Zhang et al. then established that relatively higher miR-21 oncogene expression was detected in $80 \%$ of the 30 tested surgical specimens of gastric cancer compared to normal matched tissues.

Table 1. Summary of miRNAs profiling in GC.

\begin{tabular}{|c|c|c|c|c|}
\hline Sample & $\begin{array}{l}\text { Detection } \\
\text { methods }\end{array}$ & Upregulated miRNAs & Deregulated miRNAs & Refs \\
\hline $\begin{array}{l}3 \text { pairs of GC tissue } \\
\text { and normal tissue }\end{array}$ & microarray & $\begin{array}{l}\text { miR-223, miR-106b, miR-147, miR-34a, miR-130b*, } \\
\text { miR-106a, miR-18a, miR-17, miR-98, miR-616*, } \\
\text { miR-181a-2*, miR-185, miR-1259, miR-601, miR- } \\
\text { 196a }{ }^{*} \text { miR-221*, miR-302f, miR-340*, miR-337-3p, } \\
\text { miR-520c-3p, miR-575 and miR-138 }\end{array}$ & miR-638 and miR-378 & {$[77]$} \\
\hline
\end{tabular}

\begin{abstract}
42 undifferentiated GC tissues and paired normal tissue samples and the corresponding nonneoplastic mucosa 20 pairs of primary GC and corresponding noncancerous gastric tissues

90 pretreatment GC samples and 34 normal gastric mucosal biopsy samples
\end{abstract}

6 primary GC tissue microarray

RT-PCR

microarray
qRT-PCR miR-34b, miR-34c and miR-128a miR-25, miR-106b, miR-93, miR-503, miR-18a, miR
224, miR-451, miR-18b, miR-17-5p, miR-486-5p,
miR-144, miR-552, miR-425-5p, miR-92, miR-106a, miR-223, miR-205, miR-196b, miR-19a, miR-191, let-7i, miR-185, miR-769-5p, miR-301, miR-21, miR-130b, miR-19b, miR-424, miR-484, miR-767-5p, miR-183, miR-210, miR-302c* miR-520g, miR-3245p, miR-103, miR-376b, miR-151, miR-596, miR-545, miR-221, miR-20a, miR-181b, miR-181d, miR-623, miR-519d, miR-563, miR-505, miR-107, miR-320, miR-96, miR-339, miR-181a, miR-345, miR-20b, miR-33b, miR-135b, miR-431, miR-193a, miR-550, miR-565

miR-181d, miR-181a-1, miR-a-2, miR-181c, miR-b-1, miR-181b-2, miR-21, miR-25, miR-92-1, 184 GC sample and 169 non-tumor microarray mucosae

\section{miR-92-2, miR-93, miR-17-5p, miR-106a, miR-20b,} miR-135a-1, miR-135a-2, miR-425-5p, miR-106b, miR-20a, miR-19b-1, miR-19b-2, miR-224, miR-18a, miR-135b, miR-19a, miR-345, miR-191
miR-128b, miR-129 and miR-148

miR-146a, miR-148a

let-7a, miR-126, miR-210, miR-181b, miR-197, and miR-30aa-5p

miR-146a, miR-133a, miR-625, miR-375, miR-133b, miR-195, miR-148a, miR-1, miR-26a, miR-204, let-7c, let-7a, let-7g, miR-497, miR-26b, miR-145, miR-34a, miR-143, miR-650, miR-150, miR-768-5p, let-7d, miR-203, miR-29c, let-7f, miR-30d, miR-642, miR-30c, miR-155, miR-34b, miR-551b, miR-28, let7e, let-7b, miR-212, miR-564, miR-770-5p, miR-30b, miR-30a-5p, miR-199b, miR-125a, miR-621, miR-31, miR-365, miR-381, miR-626, miR-127, miR-660, miR-342, miR-146b, miR-361, miR-489, miR-29a, miR-95, miR-567, miR-152, miR-429, miR-200b, miR-504, miR-668, miR-186, miR-135a, miR-485-5p

miR-148a, miR-148b, miR-375, miR-29b-1, miR29b-2, miR-29c, miR-152, miR-218-2, miR-451, miR30d, miR-30a-5p, miR-30b, miR-30c-1, miR-30c-2, miR-422b 
Table 2. Deregulated miRNAexpression and target genes in GC.

\begin{tabular}{|c|c|c|c|c|c|c|}
\hline miRNAs & Studied samples & $\begin{array}{l}\text { Detection } \\
\text { methods }\end{array}$ & Expression level & Target genes & Implicated processes & Refs \\
\hline miR-1 & Tissues and cell lines & qPCR & Down-regulated & $\begin{array}{l}\text { VEGF-A, EDN1, } \\
\text { MET }\end{array}$ & $\begin{array}{l}\text { proliferation and migration of tumor } \\
\text { cells and endothelial cells, }\end{array}$ & {$[41]$} \\
\hline miR-141 & Tissues and cell lines & RT-PCR & Down-regulated & ZEB1, STAT4 & Cell proliferation, apoptosis and invasion & $\begin{array}{l}{[45} \\
83]\end{array}$ \\
\hline $\begin{array}{l}\operatorname{miR}-106 b \\
\text { miR-93 }\end{array}$ & Tissues and cell lines & $\begin{array}{l}\text { miRNA micro- } \\
\text { array, }\end{array}$ & Up-regulated & $\begin{array}{l}\text { E2F1, CDKN1A } \\
(\mathrm{p} 21)\end{array}$ & Cell cycle & {$[10]$} \\
\hline & & qRT-PCR & & & & \\
\hline $\operatorname{miR}-126$ & Tissues and cell lines & qRT-PCR & $\begin{array}{l}\text { Up-regulated/ } \\
\text { Down-regulated }\end{array}$ & $\begin{array}{l}\text { PI3KR2, VEGF-A, } \\
\text { Crk, SOX2 }\end{array}$ & $\begin{array}{l}\text { cell growth and colony formation, } \\
\text { apoptosis migration and invasion, } \\
\text { cell cycle, drug-resistance, angiogenesis }\end{array}$ & $\begin{array}{l}{[22-} \\
25 \\
31]\end{array}$ \\
\hline $\begin{array}{l}\operatorname{miR}-15 a \\
\text { miR-16-1 }\end{array}$ & Tissues and cell lines & qPCR & Down-regulated & Twist1, YAP1 & $\begin{array}{l}\text { Cell proliferation, EMT, migration, } \\
\text { invasion, colony formation in vitro, } \\
\text { tumorigenicity in vivo }\end{array}$ & $\begin{array}{l}{[20,} \\
21]\end{array}$ \\
\hline miR-185 & Tissues and cell lines & qRT-PCR & Down-regulated & ARC & chemosensitivity & {$[44]$} \\
\hline $\operatorname{miR}-200 c$ & Cell lines & qRT-PCR & Down-regulated & ZEB1, ZEB2 & $\begin{array}{l}\text { EMT, Drug-resistance, invasion, } \\
\text { and migration }\end{array}$ & {$[43]$} \\
\hline miR-21 & Tissues and cell lines & $\begin{array}{l}\text { miRNA micro- } \\
\text { array, } \\
\text { qRT-PCR }\end{array}$ & Up-regulated & $\begin{array}{l}\text { PDCD4, Bcl-2, } \\
\text { Bax, PTEN }\end{array}$ & $\begin{array}{l}\text { Cell proliferation, apoptosis, invasion, } \\
\text { migration, drug-resistance }\end{array}$ & {$[5,17]$} \\
\hline miR-223 & Tissues and cell lines & RT-PCR & Up-regulated & EPB41L3 & $\begin{array}{l}\text { Cell migration and invasion in vitro } \\
\text { and in vivo }\end{array}$ & {$[80]$} \\
\hline miR-25 & Tissues and cell lines & $\begin{array}{l}\text { miRNA micro- } \\
\text { array, } \\
\text { qRT-PCR }\end{array}$ & Up-regulated & Bim & Cell apoptosis & {$[10]$} \\
\hline miR-146a & Tissues & qRT-PCR & Down-regulated & EGFR, IRAK1 & migration and invasion & {$[11]$} \\
\hline miR-29a & Tissues & qRT-PCR & Down-regulated & ITGB1 & Cell invasion, metastasis & {$[39]$} \\
\hline miR-29c & Tissues & $\begin{array}{l}\text { NGS analysis, } \\
\text { qRT-PCR }\end{array}$ & Down-regulated & ITGB1 & $\begin{array}{l}\text { Cell proliferation, adhesion, invasion } \\
\text { and tumor growth }\end{array}$ & {$[40]$} \\
\hline miR-296-5p & Tissues and cell lines & qRT-PCR & Up-regulated & CDX1 & Tumor cell growth & {$[14]$} \\
\hline miR-331-3p & Cell lines & - & - & HER2 & - & {$[42]$} \\
\hline $\operatorname{miR}-335$ & Cell lines & qRT-PCR & Down-regulated & SP1, Bcl-w & invasion and metastasis & {$[47]$} \\
\hline $\operatorname{miR}-34 a$ & Tissues & qRT-PCR & Down-regulated & PDGFR, MET & migration, invasion and proliferation & {$[19]$} \\
\hline $\operatorname{miR}-375$ & Tissues and cell lines & $\begin{array}{l}\text { miRNA micro- } \\
\text { array, } \\
\text { qRT-PCR }\end{array}$ & Down-regulated & 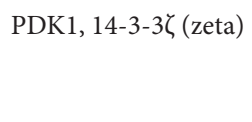 & apoptosis & {$[15]$} \\
\hline $\operatorname{miR}-423-5 p$ & Tissues and cell lines & qPCR & Up-regulated & TFF1 & $\begin{array}{l}\text { proliferation and colony formation but } \\
\text { suppress invasion in gastric cancer cells }\end{array}$ & {$[84]$} \\
\hline $\operatorname{miR}-424$ & Tissues & TCGA analysis & Up-regulated & LATS1 & $\begin{array}{l}\text { cell proliferation, invasion, } \\
\text { colony formation }\end{array}$ & {$[26]$} \\
\hline $\operatorname{miR}-425$ & - & - & Up-regulated & PTEN & cell proliferation & {$[28]$} \\
\hline $\operatorname{miR}-532-5 p$ & Tissues and cell lines & TCGA analysis & Down-regulated & NCF2 & metastasis, angiogenesis & {$[13]$} \\
\hline Let-7b & Tissues and cell lines & qRT-PCR & Down-regulated & ING1 & invasion and metastasis & {$[85]$} \\
\hline
\end{tabular}

Abbreviation: ARC: apoptosis repressor with caspase recruitment domain; CDX1: caudal-related homeobox 1; EDN1: endothelin 1; EGFR: epidermal growth factor receptor; ING1: inhibitor of growth family, member 1; EPB41L3: erythrocyte membrane protein band 4.1-like 3; IRAK: interleukin-1 receptor-associated kinase 1; ITGB1: integrin $\beta 1$; NCF2: neutrophil cytosol factor 2; NGS: next generation sequencing; SOX2: SRY (sex-determining region Y)-box 2; STAT4: Signal transducer and activator of transcription 4; SP1: specificity protein 1; TFF1: trefoil factor 1; YAP1: Yes-associated protein 1; ZBTB10: Zinc finger and BTB domain containing 10.

This miR-21 over-expression promoted cell proliferation, colony formation and growth and it increased migration and invasion $[17,18]$.

Expression of the miR-34a, miR-15a and miR-16-1 antitumor miRNAs differs to the elevated GC level of oncogenic
miRNAs because these exert negative regulation on cell proliferation, epithelial-mesenchymal transition (EMT), migration, invasion, colony formation in vitro and tumorigenicity in vivo. These are all decreased in tumor tissues compared to adjacent normal tissues. [19-21]. In addition, MiR-126 
is confirmed to be down-regulated in GC where it acts as a tumor-suppressor by repressing tumor cell growth, migration and invasion and inducing cell cycle arrest in the G0/G1 phase. It also promotes apoptosis in vitro and inhibits tumorigenicity and metastasis in vivo $[22,23]$. Moreover, Otsubo et al. recorded that miR-126 was aberrantly up-regulated in several GC cell lines and tumor tissues, and its ectopic expression contributed to GC cell growth and colony formation [25] However, MiR-126 has a well-recognized role in vascular integrity and angiogenesis, and our review established its suppressive effect on GC angiogenesis.

Intriguingly, some miRNAs' expression and function is tissues specific. For example, MiR-424 promotes GC cell growth and invasion with aberrantly high levels in gastric adenocarcinoma (GAC) tissues [26], but it is significantly down-regulated in cervical cancer tissues where it has a tumor suppressive role in inducing G1/S cell-cycle arrest, inhibiting cell migration and inducing apoptosis [27].

\section{Mechanisms underlying miRNAs de-regulation in GC}

Although miRNAs are abnormally expressed in multiple cancers, their deregulation mechanisms remain mostly elusive. The frequent causes identified include transcriptional deregulation, epigenetic modification, mutation, DNA copy number abnormality and defects in miRNA biogenetic machinery [9]. Solely or in combination, these mechanisms contribute to miRNA deregulation.

Pro-inflammatory cytokine IL- $1 \beta$ induces activation of transcription factor NF- $\kappa \mathrm{B}$ and subsequently up-regulates miR-425 expression in GC cells [28]. The miR-106b-25 cluster, including miR-106b, miR-93, and miR-25, have been demonstrated to be up-regulated by E2F1, in parallel with their host gene Mcm7. In contrast, however, E2F1 is targeted and negatively controlled by miR-106b and miR-93 which form a negative feedback loop in GC [10]. Epigenetic alterations also affect the miRNA expression in GC, and these include DNA methylation, histone modification and posttranscriptional gene regulation by other ncRNAs.

Intriguingly, $H$. pylori is involved in epigenetic silencing of tumor suppressor genes, where enhanced activity of epigenetic modification enzymes induced by the increased nitric oxide pro-inflammatory factor nitric oxide have a central role [29]. The cytotoxin-associated A gene is a well-characterized virulent factor in $H$. pylori-associated inflammation and gastric carcinogenesis, and this contributes to epigenetically silencing of let-7a and let-7c expression in rat gastric mucosal cells. This is ascribed to cooperative increase in H3K27 trimethylation and DNA methylation of CpG islands at the let-7 promoter region accomplished by increased expression of Enhancer of Zeste homologue 2 (EZH2) and DNA methyltransferase 3B (DNMT3B) [3].

Other ncRNAs also regulate miRNAs expression due to their complementary sequences to miRNAs and thus have a regulatory effect on miRNAs [30]. A significant decrease in
miR-126 level is observed in SGC-7901 cells transfected with lncRNA HOX antisense intergenic RNA (HOTAIR) cDNA [31]. The level of phosphatase and tensin homolog pseudogene 1 (PTENP1) was then observed inversely correlated with miR-106b/miR-93 in GC tissues [32], and silencing the circular RNA (circRNA) hsa_circ_0000096 up-regulated miR-200a expression but deregulated miR-224 in GC [33].

The following observations were also clear in this review. Over $50 \%$ of miRNA genes are located in fragile chromosomal regions and miRNA expression is also susceptible to gene amplification, mutation or translocation during carcinogenesis and development [12]. A germline $\mathrm{G}$ mutation identified in the coding region of miR-125a led to $40 \%$ reduction in miR-125a expression and enhanced stability of pri-miR-125a in GC [34]. In 76 GC samples, it was observed that G/C single nucleotide polymorphism (SNP) (rs2910164) in the pre-miR-146a seed sequence could lead to the downregulation of miR-146a in the GG genotype compared to the CC genotype [11]. The miR-106b-25 cluster located in intron 13 of Mcm7 on chromosome 7q22, and the amplification of this site has also been reported in gastric carcinomas [35].

Moreover, miRNA biogenesis is a complex process regulated by multiple related proteins such as Drosha, DGCR8, Dicer and Ago, and their deregulation can directly affect miRNA transcription, maturation and RISC assembly processes during miRNA biogenesis and promote tumorigenesis [9]. The down-regulation of Dicer was observed in $\mathrm{GC}$, and this correlated with poor differentiation and lymph node invasion at $\mathrm{p}<0.05$ [36].

\section{miRNA target genes in GC}

It is acknowledged that miRNAs perform functions by post-transcriptionally inhibiting the expression of oncogenic and tumor suppressor genes by base-pairing with their mRNAs. Therefore, identification of miRNA target genes is of great help in revealing the significant role of miRNAs in malignancy pathogenesis. Table 2 herein highlights miRNA GC target genes and their associated processes.

Disturbed balance between cell proliferation and growth and cell apoptosis leads to tumorigenesis, and this is delicately tuned by complex proteins and signaling cascades [37]. The Bcl-2 family members, which predominantly regulate apoptosis, are regulated by miRNAs in gastric carcinogenesis. MiR-21 inhibitors elevate the expression of the Bax pro-apoptotic molecule and coincidentally decrease expression of the anti-apoptotic molecule Bcl-2 which unlocks the stimulating effect of miR-21 on GC tumor growth [18].

Further, Bim is a BH3-only protein which can activate Bax to promote apoptosis, but this is down-regulated by miR-25, resulting in resistance to TGF $\beta$-induced GC cell apoptosis [10]. However, over-expressing the miR-93 and miR-106b members of the miR-106b-25 cluster can abolish the G1/S cycle arrest induced by TGF $\beta$ by targeting p 21 which blocks passage through the cell cycle through its repressive effects on 
both cyclin-dependent kinases and proliferating-cell nuclear antigen $[10,38]$. The suppressive effects of blocking the cell cycle and inducing apoptosis by caudal-related homeobox 1 (CDX1), which is an intestinal-specific transcription factor involved in gastric intestinal metaplasia (IM), are attenuated by miR-296-5p; thus resulting in GC growth [14].

In addition to genes implicated in carcinogenesis, miRNAs can also regulate targets affecting tumor progression, and especially metastasis which is the most lethal aspect of the oncogenic process. Several cell biological activities are controlled in multi-step metastasis. These include adhesion, angiogenesis, migration and invasion which enable tumor cells to disseminate from their primary locations, enter the circulation and form secondary colonies at other sites [1]. ITGB1 (Integrin $\beta 1$ ) is a cell adhesion molecule which mediates mutual adhesion between cells and extra-cellular matrix (ECM). This is targeted by miR-29, and enhanced ITGB1 expression due to decreased miRNA-29 in GC also promotes tumor metastasis $[39,40]$.

In addition, Twist1 promotes EMT by regulating the $\mathrm{N}$-cadherin, $\alpha$-SMA and Fibronectin EMT-related genes and thus contributes to GC cells migration and invasion. This oncogenic effect can then be repressed by the interaction of miR-15a-3p and miR-16-1-3p with the miRNA recognition elements (MREs) on the Twist1 3'-UTR [20]. Xie et al. further reported that ectopic expression of miR-1 in GC cells can inhibit endothelial cell migration and tube formation due to down-regulated endothelial vascular growth factor-A (VEGF-A) and endothelin 1 (EDN1) [41].

Some target genes have now become significant therapeutic sites in malignancies. These include human epidermal growth factor receptor 2 (HER2), c-Met and VEGF-A. In addition, Trastuzumab, a monoclonal antibody against the HER2 transmembrane tyrosine kinase receptor, can be combined with chemotherapy in standard treatment for the $11-20 \%$ of patients affected by HER 2 amplification $[42,43]$. Although there is frequently acquired resistance to Trastuzumab in GC patients, enhanced TGF- $\beta$-induced-EMT from impaired miR-200c on ZEB1 and ZEB2 regulation may counteract this [43]. Additional target genes implicated in drug-resistance include the positive role of the apoptotic repressor in the caspase recruitment domain (ARC) in the impaired response to DDP/ doxorubicin, and PTEN's negative role in DDP tolerance $[5,44]$.

Notably, the crosstalk between several ncRNAs and mRNAs has attracted increasing attention in regulating ncRNA transcription (especially circRNAs and lncRNAs). Here, mRNAs can competitively bind to the same miRNA as competing endogenous RNAs (ceRNAs) or miRNA sponges because of shared MREs; thus affecting the posttranscriptional regulation of target mRNAs by miRNAs [30]. These interactions are important in the development of GC because they offer additional modification of gene posttranscriptional regulation. Here, Zhou et al. reported that lncRNA H19 attenuates the negative regulation of miR-141 on its target gene ZEB1, thus promoting GC proliferation and migration [45].

Research has also recorded that over-expressed lncRNA LINC01410 inhibited miR-532-5p, leading to impaired de-regulation of neutrophil cytosol factor 2 (NCF2) and subsequent activation of the NF- $\kappa B$ pathway. NF- $\kappa B$ then activated the LINC01410 transcription level through the $\mathrm{NF}-\mathrm{kB} / \mathrm{p} 65$-binding site in the LINC01410 promoter region and this formed a positive feedback circuit contributing to GC angiogenesis and metastasis [13]. Increased circLARP4 can also act as a ceRNA for miR-424 to up-regulate expression of the large tumor suppressor kinase 1 (LATS1) target gene, and consequently attenuate the GC cell proliferation induced by miR-424 [26].

\section{Clinical application of miRNAs in GC}

MiRNAs as useful biomarkers. As previously discussed, significantly different miRNA expression occurs in tumor tissues and controls, and the miRNA expression signatures can therefore distinguish GC and normal tissues. Moreover, miRNAs also correlate with GC progression and clinicalpathological characteristics, so miRNA profiling can classify GC patients in prognostic groups and choose appropriate treatment strategies.

Higher miR-214 levels positively associate with invasion depth, metastasis and TNM stages. In addition, the GC patient Kaplan-Meier survival curves determined strong correlation between miR-214 level and survival time $(\mathrm{p}=0.031)$ [46]. In a similar study of $70 \mathrm{GC}$ samples, low miR-335 tumor suppressor level was associated with lymph-node metastasis $(\mathrm{p}<0.001)$. lymphatic vessel invasion, advanced $\mathrm{pT}$ stage and higher $\mathrm{pN}$ stage $($ all $\mathrm{p}<0.05)$ [47]. Li et al. analyzed follow-up data of $38 \mathrm{GC}$ stage I patients after surgery, and concluded that combined high miR-23a levels and low PTEN indicated less disease-free survival time (DFS) [48]. Similarly, lower miR-146a level correlated with both increased lymph node metastasis and venous invasion, and multivariate analysis then indicated that miR-146a expression could well be an independent prognostic predictor of overall GC survival [11].

In addition to circulating miRNA levels in tumor tissues, these can also be detected in serum, plasma, urine and gastric juice. Numerous studies have proven the great promise of circulating miRNAs as novel non-invasive biomarkers because of their high stability, close relationship with disease status and easy measurement. For example, Zhu et al. identified accurate early-stage gastric cancer detection from signatures of over-expressed miR-16, miR-25, miR-92a, miR-451 and miR-486-5p in GC patient plasma [49]. Similarly, miR-185, miR-20a, miR-210, miR-25 and miR-92b in peripheral plasma were confirmed as diagnostically significant for GC [50].

Low serum miR-203 levels are a proven independent risk factor for lymph node, peritoneal, and distant metastases and consequent poor prognosis for GC patients [51], and the 
miRNAs in gastric juice peculiar to stomach tissues may also provide more specific and effective GC biomarkers [52]. Cui et al. demonstrated that detecting miR-106a level in gastric juice had more reliable diagnostic value than in peripheral blood (AUC 0.871 to 0.684 ), and the combined detection of gastric juice miR-21/miR-106a and carcino-embrionic antigen (CEA) was more valuable than using serum CEA alone [53].

miRNA gene mutations and SNPs influence their transcription, maturation and miRNA-mediated regulation of target genes, and this makes miRNAs SNPs susceptible to numerous cancers [54]. Sun et al. demonstrated that the common rs895819 A/G polymorphism in the miR-27a genome correlates with susceptibility to GC, and subjects with $A G+G G$ genotypes had significantly increased risk in gastric cancer compared to the AA genotype (adjusted $\mathrm{OR}=1.48$ ) [54]. SNPs in miR-146a rs2910164, miR-196a-2 rs11614913 and miR-149 rs2292832 are also associated with GC susceptibility [55]. Therefore, detecting these SNPs will help screening high GC risk. It is noteworthy that the methylation level of miRNAs can also be predictive of GC. For example, miR-34b/c methylation in non-cancerous gastric mucosa can be a useful biomarker in predicting metachronous GC [56].

MiRNAs as potential therapeutic targets. The close association between miRNA deregulation and GC pathogenesis enables the restoration of tumor-suppressive miRNAs and/or inhibiting oncogenic miRNAs to be potential strategies against this tumor. Significantly impaired ability of proliferation, migration and colony formation is observed when transfecting BGC-823 and MKN-74 cells (GC cell lines) with miR-21 inhibitor compared to the control group $(\mathrm{p}<0.05)$ [18]. Ectopic expression of miR-141 by transfecting GC cells with miR-141 mimics can also provide almost $40 \%$ inhibition to proliferation and a prominent reduction in invasion [45].

miRNAs have also been tested in vivo. Han et al's xenograft nude mouse model recorded tumor growth in mice implanted with miR-29c over-expressing GC cells was significantly slower than in those with untreated parental GC cells $(p<0.0001)$. Injecting the tumor with miR-29c mimics by liposome delivery also results in remarkable inhibition of tumor growth [40], and bioluminescence imaging and analysis showed miR-137 had anti-metastatic effect in in vivo lung tissue [57].

Consistent with their regulation of cell apoptosis, miRNAs also exert significant effects in chemotherapies mediated by apoptotic signaling pathways. It has been demonstrated that the level of miR-21 in the DDP resistant GC cell line SGC7901/DDP was significantly higher than its SGC7901 parental cell line $(\mathrm{p}<0.001)$; and further, knocking miR-21 down can promote apoptosis and decrease viability in the SGC7901/DDP cell line treated with DDP [5]. Similarly, miR-19a/b are up-regulated in SGC7901/VCR and SGC7901/
ADR cell lines, and the enhanced response to CDDP, 5-FU and ADR can be acquired via suppressing miR-19a/b level in SGC7901/VCR cells [58].

In contrast, $\mathrm{Li}$ et al. reported that ectopic miR-185 expression in GC cells enhanced DDP or doxorubicin-induced apoptosis, and knockdown of endogenous miR-185 prevented cisplatin or doxorubicin-induced GC cell apoptosis. Further, tumor growth in the established GC xenograft model is inhibited by the combined therapy of enforced miR-185 expression and a low dose of doxorubicin. This is as effective as highdose doxorubicin therapy [44], and miRNAs are therefore promising targets for improving chemotherapy treatment by modifying drug-sensitivity and helping to formulate appropriate chemotherapy by predicting therapeutic response.

The CSC hypothesis postulates that initiation and maintenance of cancers are attributed to a small subset of cancer cells, called CSCs [59]. Primarily, CSCs are defined as rare, quiescent and capable of self-renewal and multi-lineage differentiation [60]. These cells have been a critical cause of tumor metastasis, recurrence and chemo and radio-resistance. While conventional anti-carcinogenic treatment limits CSC effects, novel therapeutic strategies for eradicating CSCs are essential for successful cancer cure; and the first challenge lies in recognizing CSCs in the tumor mass. Here, stem markers, spheroid formation assay and selection of side-population (SP) cells with high efflux ability of Hoechst dyes are feasible $[61,62]$.

CD44 can identify tumor cells with CSCs properties in GC $[60,63]$, and several studies have observed significantly different expression profiling of specific miRNAs between gastric CSCs and other tumor cells, thus implying the potential application of miRNAs in recognizing CSCs $[61,63]$ (Table 3). Moreover, restoring deregulated miRNAs can modulate CSC characteristics, so miRNAs could be therapeutic targets in CSC treatment. For example, miR-106b knockdown could suppress EMT, self-renewal and the invasive capacity and CSC marker expression in CD44 (+) GC cells [63].

Blockages to miRNA clinical application. Despite the great potential miRNAs manifest in GC management, there are many blockages to the transition from laboratory studies to clinical practice. While miRNAs have good sensitivity and specificity as biomarkers for GC diagnosis and prognosis with greater promise than in current use, the following factors restrict increased application; (1) current research on miRNAs' predictive ability frequently involves small-size coherents. This is a major cause of study discrepancy; (2) significant effort is required to integrate accumulated research; (3) population-based differences in miRNA deregulation must be considered when these are used as biomarkers for GC diagnosis and prognosis and (4) an appropriate standard testing system is lacking for clinical practice, and any instituted system must have a feasible threshold and quality control. 
Table 3. MiRNAs and cancer stem cells in GC.

\begin{tabular}{|c|c|c|c|c|}
\hline miRNAs alteration & CSCs Recognition & Effects & Implicated signaling & Ref \\
\hline miR-501-5p & $\begin{array}{l}\text { CD44, CD133, Bmi1, Nanog, MYC and } \\
\text { SOX2 expression; percentage of the side- } \\
\text { population of cells; tumor spheres formation }\end{array}$ & Promotion in self-renewal & Wnt/ $\beta$-catenin pathway & {$[86]$} \\
\hline $\operatorname{miR}-34 a$ & tumor spheres formation & Inhibition in self-renewal & $\begin{array}{l}\text { Bcl-2, Notch, and HMGA2 } \\
\text { (targets of miR-34a) }\end{array}$ & {$[87]$} \\
\hline $\begin{array}{l}\text { miR-106b, miR-93, miR-25 } \\
\text { (miR-106b family) } \uparrow\end{array}$ & $\mathrm{CD} 44(+)$ & $\begin{array}{l}\text { Promotion in EMT, self-renewal } \\
\text { and invasion }\end{array}$ & TGF- $\beta /$ Smad pathway & {$[63]$} \\
\hline miR-21 and miR-302 $\uparrow$, let-7a $\downarrow$ & $\mathrm{CD} 44(+)$ & Not described & Not described & {$[61]$} \\
\hline $\begin{array}{l}\text { miR-19b, miR-20a and miR-92a } \\
\text { (miR-17-92 cluster) } \uparrow\end{array}$ & $\operatorname{EpCAM}(+) / C D 44(+)$ & $\begin{array}{l}\text { Promotion in proliferation, } \\
\text { metastasis, self-renewal }\end{array}$ & Wnt/ $\beta$-catenin pathway & {$[62]$} \\
\hline $\begin{array}{l}\text { miR-4270, miR-483-5p, miR- } \\
\text { 642b-3p, miR-4669, miR-4290, } \\
\text { miR-483-3p, miR-4778-5p, miR- } \\
451 b, \text { miR-4763-3p } \uparrow \text {, other } 173 \\
\text { miRNAs } \downarrow\end{array}$ & spheroid body formation assay & Not described & $\begin{array}{l}\text { Notch, Wnt/ } \beta \text {-catenin, } \\
\text { MAPK, } \\
\text { mTOR, JAK-STAT pathway }\end{array}$ & {$[88]$} \\
\hline
\end{tabular}

The therapeutic effect of miRNAs also contains issues which must be settled before miRNAs are accepted in clinical application; (1) current studies testing miRNA potential curative effects are carried out in isolated GC cell lines or animal models, and therefore dose optimization should be investigated when transforming study results to clinical application; (2) safe and effective vectors are required for delivering miRNA to a specific tissue or disease site; (3) miRNA therapeutic effects vary in different contexts because of their wide interactions with different target genes and signaling pathways. Research results should be interpreted with caution and possible off-target effects must also be considered and (4) immune activation should be minimized when miRNA mimics or antagomirs are used in GC treatment.

\section{The role of lncRNAs in GC}

Genome-wide studies in the last decade showed that only $2 \%$ of the mammalian genome encodes mRNAs; with most transcribed as ncRNAs [64]. There is division into two categories: large RNAs over 50nt and smaller ones. The former category includes lncRNA, small nucleolar RNA, circRNA, transfer RNA and ribosomal RNA; and the latter category has miRNA, small interfering RNA and Piwi-interacting RNA [65]. Despite their inability to encode protein, RNAs act as transcriptional and post-transcriptional regulators and chromatin-modifying complex guides, and thus have prominent roles in physiological and pathological conditions [64]. Evidence has provided new information on miRNA, lncRNA and ncRNA involvement in CG pathogenesis and development.

LncRNAs have over 200 nucleotides but lack an open reading frame over 100 amino acids [66]. They are subdivided into exonic, intronic, overlapping and inter-genic
lncRNAs, dependent on location with the nearest proteincoding transcripts [67]. These heterogeneous lncRNAs fulfill a broad spectrum of cellular functions, including chromatin modification and transcriptional and post-transcriptional regulation. Deregulated lncRNAs also regulate GC progression $[65,68]$ and recent studies demonstrate that aberrant lncRNA expression contributes to malignant GC phenotypes, such as carcinogenicity, tumor growth and metastasis. These functions are performed through regulation of proliferation, apoptosis, invasion and migration.

Up-regulation of oncogenic lncRNAs and tumor-suppressive lost expression co-operate in gastric cancer initiation and development. HOTAIR is a typical oncogenic lncRNA which binds Polycomb Repressive Complex 2 (PRC2) and LSD1 (lysine specific demethylase 1)/CoREST (Co-repressor of RE1-silencing transcription factor)/REST complexes. This directs the complexes to specific gene sites providing H3K27 methylation, H3K4 de-methylation and ultimate gene silencing [69]. HOTAIR is significantly up-regulated in GC, and its siRNA knockdown inhibits GC cell proliferation, migration and invasion and concurrently enhances anoikis rate. Moreover, injecting HOTAIR siRNA-transfected GC cells into nude mice represses both xenograft tumor growth and peritoneal metastases [70].

Up-regulated lncRNA highly expressed gastric carcinoma transcript 1 (GHET1) is another lncRNA in GC, and this facilitates tumor cell proliferation and xenograft tumor growth in nude mice. Mechanistic analysis indicates that the promotion effects of GHET1 are due to the increased c-Myc mRNA stability and expression mediated by GHET1's association with insulin-like growth factor 2 mRNA binding protein 1 (IGF2BP1). This enhanced the physical interaction between c-Myc mRNA and IGF2BP1 protein [71]. In contrast, the lncRNAs maternally expressed gene 3 (MEG3) and FENDRR were down-regulated in GC and inhibited 
cell proliferation, migration and invasion and promoted cell apoptosis by modulating p53, fibronectin 1 and matrix metalloproteinase 2 (MMP2)/MMP9 [72, 73].

Potential lncRNA clinical implications have also been investigated in GC. For example, Arita et al. observed that lncRNA H19 plasma level was significantly higher in patients than in healthy controls $(\mathrm{p}=0.029)$ [74], and Dong et al. measured 39 lncRNAs in the serum from 110 GC patients, 106 healthy subjects and 15 gastric peptic ulcer patients. These authors identified a three-lncRNA diagnostic signature consisting of lncRNAs cancer up-regulated drug resistant (CUDR), long stress-induced non-coding transcript 5 (LSINCT-5) and PTENP1. They then demonstrated that the signature had better diagnostic accuracy than the commonly used CEA and CA19-9 biomarkers. (with areas under the curve (AUC): 0.92 , 95\%CI: $0.807-0.974$ compared to 0.574 , 95\%CI: 0.432-0.708 and: 0.580, 95\%CI: 0.438-0.713; respectively) [75].

lncRNA expression levels in GC tumor tissues also possess prognostic predictive value. Here, the highly-expressed HOTAIR could be an independent prognostic and risk factor for GC peritoneal metastases [70]. Decreased MEG3 level also correlated with larger tumor size, advanced pathological stage and deeper invasion, and GC patients therefore had significantly worse prognosis than those with higher levels $(\mathrm{P}<0.001)$ [73]. There are also lncRNAs, such as FENDRR and growth arrest-specific transcript 5 (GAS5), associated with the 5-year survival rate of GC patients [76]. Unfortunately, although the anti-tumor effects achieved by lncRNA modulation set them as novel GC therapeutic targets, some caveats impede their clinical application.

\section{Conclusion}

This review summarizes deregulated miRNAs' contribution to gastric cancer pathogenesis. It then investigated malignant tumor growth, metastasis and drug-resistant GC phenotypes by miRNA regulation of downstream target genes involved in cell differentiation, proliferation, migration, invasion and apoptosis. The genetic alteration and epigenetic modification mechanisms underlying miRNAs' aberrant expression are also identified

The cellular and molecular deregulation of miRNAs in GC participation promotes their trial in clinical application. The aberrant levels of miRNAs in tumor tissues, and also in plasma, serum and gastric juice, could well serve as additional diagnostic and prognostic biomarkers for GC patients, and SNPs and specific miRNAs' DNA methylation may determine GC risk factors. Thus, deregulated miRNAs present a promising anti-cancer therapeutic target in GC; especially considering their effects in modifying chemo-resistance and modulating gastric CSC action.

Unfortunately, blocking factors persist in transforming laboratory results into clinical application. They include ensuring safe and effective vectors, avoiding undesired off-target effects and instituting standardized testing systems. These factors are therefore appropriate research themes for future gastric cancer elucidation.

Acknowledgements: The study was supported by funding from National Science Foundation Grants of China (No. 81160307) and (No. 81560395), the Jiangxi Science \& Technology Pillar Program and the Science Foundation for Young Scholars of Jiangxi Province (No. 2007GQY1167), and Voyage Project of Jiangxi Province Science and Technology Association.

\section{Reference}

[1] HUNG-WEI P, SUNG-CHOU L, KUO-WANG T. MicroRNA Dysregulation in Gastric Cancer. Current Pharmaceutical Design 2013; 19: 1273-1284. https://doi. org/10.2174/138161213804805621

[2] VAN CUTSEM E, SAGAERT X, TOPAL B, HAUSTERMANS K, PRENEN H. Gastric cancer. Lancet 2016; 388: 2654-2664. https://doi.org/10.1016/S0140-6736(16)30354-3

[3] HAYASHI Y, TSUJII M, WANG J, KONDO J, AKASAKA $\mathrm{T}$ et al. CagA mediates epigenetic regulation to attenuate let-7 expression in Helicobacter pylori-related carcinogenesis. Gut 2013; 62: 1536-1546. https://doi.org/10.1136/ gutjnl-2011-301625

[4] PLUMMER M, FRANCESCHI S, VIGNAT J, FORMAN D, DE MARTEL C. Global burden of gastric cancer attributable to Helicobacter pylori. Int J Cancer 2015; 136: 487-490. https://doi.org/10.1002/ijc.28999

[5] YANG SM, HUANG C, LI XF, YU MZ, HE Y et al. miR-21 confers cisplatin resistance in gastric cancer cells by regulating PTEN. Toxicology 2013; 306: 162-168. https://doi. org/10.1016/j.tox.2013.02.014

[6] DIGKLIA A, WAGNER AD. Advanced gastric cancer: Current treatment landscape and future perspectives. World J Gastroenterol 2016; 22: 2403-2414. https://doi.org/10.3748/ wjg.v22.i8.2403

[7] VOINNET O. Origin, biogenesis, and activity of plant microRNAs. Cell 2009; 136: 669-687. https://doi.org/10.1016/j. cell.2009.01.046

[8] HA M, KIM VN. Regulation of microRNA biogenesis. Nat Rev Mol Cell Biol 2014; 15: 509-524. https://doi.org/10.1038/ nrm3838

[9] DENG S, CALIN GA, CROCE CM, COUKOS G, ZHANG L. Mechanisms of microRNA deregulation in human cancer. Cell Cycle 2008; 7: 2643-2646. https://doi.org/10.4161/ cc.7.17.6597

[10] PETROCCA F, VISONE R, ONELLI MR, SHAH MH, NICOLOSO MS et al. E2F1-regulated microRNAs impair TGFbeta-dependent cell-cycle arrest and apoptosis in gastric cancer. Cancer Cell 2008; 13: 272-286. https://doi. org/10.1016/j.ccr.2008.02.013

[11] KOGO R, MIMORI K, TANAKA F, KOMUNE S, MORI M. Clinical Significance of miR-146a in Gastric Cancer Cases. Clin Cancer Res 2011; 17: 4277-4284. https://doi. org/10.1158/1078-0432.CCR-10-2866 
[12] CALIN GA, SEVIGNANI C, DUMITRU CD, HYSLOP T, $\mathrm{NOCH} \mathrm{E}$ et al. Human microRNA genes are frequently located at fragile sites and genomic regions involved in cancers. Proc Natl Acad Sci U S A 2004; 101: 2999-3004. https:// doi.org/10.1073/pnas.0307323101

[13] ZHANG JX, CHEN ZH, CHEN DL, TIAN XP, WANG CY et al. LINC01410-miR-532-NCF2-NF-kB feedback loop promotes gastric cancer angiogenesis and metastasis. Oncogene 2018; 37: 2660-2675. https://doi.org/10.1038/s41388-0180162-y

[14] LI T, LU YY, ZHAO XD, GUO HQ, LIU CH et al. MicroRNA-296-5p increases proliferation in gastric cancer through repression of Caudal-related homeobox 1. Oncogene 2014; 33: 783-793. https://doi.org/10.1038/onc.2012.637

[15] TSUKAMOTO Y, NAKADA C, NOGUCHI T, TANIGAWA M, NGUYEN LT et al. MicroRNA-375 Is Downregulated in Gastric Carcinomas and Regulates Cell Survival by Targeting

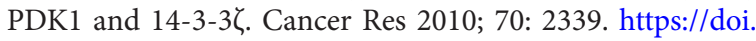
org/10.1158/0008-5472.CAN-09-2777

[16] LI L, ZHU X, SHOU T, YANG L, CHENG X et al. MicroRNA-28 promotes cell proliferation and invasion in gastric cancer via the PTEN/PI3K/AKT signalling pathway. Mol Med Rep 2017; 17: 4003-4010. https://doi.org/10.3892/ mmr.2017.8299

[17] ZHANG BG, LI JF, YU BQ, ZHU ZG, LIU BY et al. microRNA-21 promotes tumor proliferation and invasion in gastric cancer by targeting PTEN. Oncol Rep 2012; 27: 1019-1026. https://doi.org/10.3892/or.2012.1645

[18] PING W, QUNYE G, DONGMEI Z, ZE Y, YAOBO S et al. miR-21 Inhibitors Modulate Biological Functions of Gastric Cancer Cells via PTEN/PI3K/mTOR Pathway. DNA Cell Biol 2018; 37: 38-45. https://doi.org/10.1089/dna.2017.3922

[19] PENG Y, GUO JJ, LIU YM, WU XL. MicroRNA-34A inhibits the growth, invasion and metastasis of gastric cancer by targeting PDGFR and MET expression. Biosci Rep 2014; 34: e00112. https://doi.org/10.1042/BSR20140020

[20] WANG T, HOU J, LI Z, ZHENG Z, WEI J et al. miR-15a-3p and miR-16-1-3p Negatively Regulate Twist1 to Repress Gastric Cancer Cell Invasion and Metastasis. Int J Biol Sci 2017; 13: 122-134. https://doi.org/10.7150/ijbs. 14770

[21] KANG W, TONG JHM, LUNG RWM, DONG Y, ZHAO $\mathrm{J}$ et al. Targeting of YAP1 by microRNA-15a and microRNA-16-1 exerts tumor suppressor function in gastric adenocarcinoma. Mol Cancer 2015; 14: 10. https://doi.org/10.1186/ s12943-014-0274-0

[22] LIU LY, WANG W, ZHAO L, GUO B, YANG J et al. miR126 inhibits growth of SGC-7901 cells by synergistically targeting the oncogenes PI3KR2 and Crk, and the tumor suppressor PLK2. Int J Oncol 2014; 45: 1257-1265. https://doi. org/10.3892/ijo.2014.2516

[23] FENG R, CHEN X, YU Y, SU L, YU B et al. miR-126 functions as a tumour suppressor in human gastric cancer. Cancer Lett 2010; 298: 50-63. https://doi.org/10.1016/j.canlet.2010.06.004

[24] CHEN H, LI L, WANG S, LEI Y, GE Q et al. Reduced miR126 expression facilitates angiogenesis of gastric cancer through its regulation on VEGF-A. Oncotarget 2014; 5: 11873-11885. https://doi.org/10.18632/oncotarget.2662
[25] OTSUBO T, AKIYAMA Y, HASHIMOTO Y, SHIMADA S, GOTO K et al. MicroRNA-126 Inhibits SOX2 Expression and Contributes to Gastric Carcinogenesis. PLoS One 2011; 6: e16617. https://doi.org/10.1371/journal.pone.0016617

[26] ZHANG J, LIU H, HOU L, WANG G, ZHANG R et al. Circular RNA_LARP4 inhibits cell proliferation and invasion of gastric cancer by sponging miR-424-5p and regulating LATS1 expression. Mol Cancer 2017; 16: 151. https://doi. org/10.1186/s12943-017-0719-3

[27] XU J, LI Y, WANG F, WANG X, CHENG B et al. Suppressed miR-424 expression via upregulation of target gene Chk1 contributes to the progression of cervical cancer. Oncogene 2013; 32: 976-987. https://doi.org/10.1038/onc.2012.121

[28] MA J, LIU J, WANG Z, GU X, FAN Y et al. NF-kappaBdependent MicroRNA-425 upregulation promotes gastric cancer cell growth by targeting PTEN upon IL- $1 \beta$ induction. Mol Cancer 2014; 13: 40. https://doi.org/10.1186/1476-459813-40

[29] VALENZUELA MA, CANALES J, CORVAL N AH, QUEST AFG. Helicobacter pylori-induced inflammation and epigenetic changes during gastric carcinogenesis. World J Gastroenterol 2015; 21: 12742-12756. https://doi.org/10.3748/ wjg.v21.i45.12742

[30] TAY Y, RINN J, PANDOLFI PP. The multilayered complexity of ceRNA crosstalk and competition. Nature 2014; 505: 344-352. https://doi.org/10.1038/nature12986

[31] YAN J, DANG Y, LIU S, ZHANG Y, ZHANG G. LncRNA HOTAIR promotes cisplatin resistance in gastric cancer by targeting miR-126 to activate the PI3K/AKT/MRP1 genes. Tumour Biol 2016; 37: 16345-16355. https://doi. org/10.1007/s13277-016-5448-5

[32] ZHANG R, GUO Y, MA Z, MA G, XUE Q et al. Long noncoding RNA PTENP1 functions as a ceRNA to modulate PTEN level by decoying miR-106b and miR-93 in gastric cancer. Oncotarget 2017; 8: 26079-26089. https://doi. org/10.18632/oncotarget.15317

[33] LI P, CHEN H, CHEN S, MO X, LI T et al. Circular RNA 0000096 affects cell growth and migration in gastric cancer. Br J Cancer 2017; 116: 626-633. https://doi.org/10.1038/ bjc. 2016.451

[34] SHANG H, WANG T, SHANG F, HUANG K-M, LI Y-Q. A germline mutation in the miR-125a coding region reduces miR-125a expression and is associated with human gastric cancer. Mol Med Rep 2014; 10: 1839-1844. https://doi. org/10.3892/mmr.2014.2441

[35] WEISS MM, KUIPERS EJ, POSTMA C, SNIJDERS AM, PINKEL D et al. Genomic alterations in primary gastric adenocarcinomas correlate with clinicopathological characteristics and survival. Cell Oncol 2004; 26: 307-317.

[36] ZHANG J, ZHANG XH, WANG CX, LIU B, FAN XS et al. Dysregulation of MicroRNA biosynthesis enzyme Dicer plays an important role in gastric cancer progression. Int J Clin Exp Pathol 2014; 7: 1702-1707.

[37] VARA JÁF, CASADO E, DE CASTRO J, CEJAS P, BELDA-INIESTA $C$ et al. PI3K/Akt signalling pathway and cancer. Cancer Treat Rev 2004; 30: 193-204. https://doi. org/10.1016/j.ctrv.2003.07.007 
[38] BRUGAROLAS J, CHANDRASEKARAN C, GORDON JI, BEACH D, JACKS T et al. Radiation-induced cell cycle arrest compromised by p21 deficiency. Nature 1995; 377: 552-557. https://doi.org/10.1038/377552a0

[39] HE B, XIAO YF, TANG B, WU YY, HU CJ et al. hTERT mediates gastric cancer metastasis partially through the indirect targeting of ITGB1 by microRNA-29a. Sci Rep 2016; 6: 21955. https://doi.org/10.1038/srep21955

[40] HAN TS, HUR K, XU G, CHOI B, OKUGAWA Y et al. MicroRNA-29c mediates initiation of gastric carcinogenesis by directly targeting ITGB1. Gut 2015; 64: 203-214. https://doi. org/10.1136/gutjnl-2013-306640

[41] XIE M, DART DA, GUO T, XING X-F, CHENG X-J et al. MicroRNA-1 acts as a tumor suppressor microRNA by inhibiting angiogenesis-related growth factors in human gastric cancer. Gastric Cancer 2018; 21: 41-54. https://doi. org/10.1007/s10120-017-0721-X

[42] LIU X-H, SUN M, NIE F-Q, GE Y-B, ZHANG E-B et al. Lnc RNA HOTAIR functions as a competing endogenous RNA to regulate HER2 expression by sponging miR-331$3 p$ in gastric cancer. Mol Cancer 2014; 13: 92. https://doi. org/10.1186/1476-4598-13-92

[43] ZHOU X, MEN X, ZHAO R, HAN J, FAN Z et al. miR-200c inhibits TGF- $\beta$-induced-EMT to restore trastuzumab sensitivity by targeting ZEB1 and ZEB2 in gastric cancer. Cancer Gene Ther 2018; 25: 68-76. https://doi.org/10.1038/s41417017-0005-y

[44] LI Q, WANG JX, HE YQ, FENG C, ZHANG XJ et al. MicroRNA-185 regulates chemotherapeutic sensitivity in gastric cancer by targeting apoptosis repressor with caspase recruitment domain. Cell Death Dis 2014; 5: e1197. https://doi. org/10.1038/cddis.2014.148

[45] ZHOU X, YE F, YIN C, ZHUANG Y, YUE G et al. The Interaction Between MiR-141 and lncRNA-H19 in Regulating Cell Proliferation and Migration in Gastric Cancer. Cell Physiol Biochem 2015; 36: 1440-1452. https://doi. org/10.1159/000430309

[46] YANG TS, YANG XH, WANG XD, WANG YL, ZHOU B et al. MiR-214 regulate gastric cancer cell proliferation, migration and invasion by targeting PTEN. Cancer Cell Int 2013; 13: 68. https://doi.org/10.1186/1475-2867-13-68

[47] XU Y, ZHAO F, WANG Z, SONG Y, LUO Y et al. MicroRNA-335 acts as a metastasis suppressor in gastric cancer by targeting Bcl-w and specificity protein 1 . Oncogene 2012; 31 : 1398-1407. https://doi.org/10.1038/onc.2011.340

[48] LI L, ZHANG J, PAN Q, LEI C. MicroRNA-23a regulates cell migration and invasion by target PTEN in gastric cancer. Int J Clin Exp Pathol 2016; 9: 877-887.

[49] ZHU C, REN C, HAN J, DING Y, DU J et al. A five-microRNA panel in plasma was identified as potential biomarker for early detection of gastric cancer. Br J Cancer 2014; 110 : 2291-2299. https://doi.org/10.1038/bjc.2014.119

[50] ZHOU X, ZHU W, LI H, WEN W, CHENG W et al. Diagnostic value of a plasma microRNA signature in gastric cancer: a microRNA expression analysis. Sci Rep 2015; 5: 11251. https://doi.org/10.1038/srep11251
[51] IMAOKA H, TOIYAMA Y, OKIGAMI M, YASUDA H, SAIGUSA $S$ et al. Circulating microRNA-203 predicts metastases, early recurrence, and poor prognosis in human gastric cancer. Gastric Cancer 2016; 19: 744-753. https:// doi.org/10.1007/s10120-015-0521-0

[52] TOIYAMA Y, OKUGAWA Y, GOEL A. DNA methylation and microRNA biomarkers for noninvasive detection of gastric and colorectal cancer. Biochem Biophys Res Commun 2014; 455: 43-57. https://doi.org/10.1016/j. bbrc.2014.08.001

[53] CUI L, ZHANG X, YE G, ZHENG T, SONG H et al. Gastric juice MicroRNAs as potential biomarkers for the screening of gastric cancer. Cancer 2013; 119: 1618-1626. https://doi. org/10.1002/cncr.27903

[54] SUN Q, GU H, ZENG Y, XIA Y, WANG Y et al. Hsa-mir27a genetic variant contributes to gastric cancer susceptibility through affecting miR-27a and target gene expression. Cancer Sci 2010; 101: 2241-2247. https://doi. org/10.1111/j.1349-7006.2010.01667.x

[55] XU Q, LIU JW, YUAN Y. Comprehensive assessment of the association between miRNA polymorphisms and gastric cancer risk. Mutat Res Rev Mutat Res 2015; 763: 148-160. https://doi.org/10.1016/j.mrrev.2014.09.004

[56] SUZUKI R, YAMAMOTO E, NOJIMA M, MARUYAMA $\mathrm{R}$, YAMANO H-O et al. Aberrant methylation of microR$\mathrm{NA}-34 \mathrm{~b} / \mathrm{c}$ is a predictive marker of metachronous gastric cancer risk. J Gastroenterol 2014; 49: 1135-1144. https:// doi.org/10.1007/s00535-013-0861-7

[57] WU L, CHEN J, DING C, WEI S, ZHU Y et al. MicroRNA-137 Contributes to Dampened Tumorigenesis in Human Gastric Cancer by Targeting AKT2. PLoS One 2015; 10: e0130124. https://doi.org/10.1371/journal. pone. 0130124

[58] WANG F, LI T, ZHANG B, LI H, WU Q et al. MicroRNA-19a/b regulates multidrug resistance in human gastric cancer cells by targeting PTEN. Biochem Biophys Res Commun 2013; 434: 688-694. https://doi.org/10.1016/j. bbrc.2013.04.010

[59] GUO W, LASKY JL, WU H. Cancer Stem Cells. Pediatr Res 2006; 59: 59R-69R. https://doi.org/10.1203/01. pdr.0000203592.04530.06

[60] TAKAISHI S, OKUMURA T, TU S, WANG SOPHIE SW, SHIBATA $W$ et al. Identification of Gastric Cancer Stem Cells Using the Cell Surface Marker CD44. Stem Cells 2009; 27: 1006-1020. https://doi.org/10.1002/stem.30

[61] GOLESTANEH AZADEH F, ATASHI A, LANGROUDI L, SHAFIEE A, GHAEMI $\mathrm{N}$ et al. miRNAs expressed differently in cancer stem cells and cancer cells of human gastric cancer cell line MKN-45. Cell Biochem Funct 2012; 30: 411-418. https://doi.org/10.1002/cbf.2815

[62] WU Q, YANG Z, WANG F, HU S, YANG L et al. MiR$19 b / 20 a / 92 a$ regulates the self-renewal and proliferation of gastric cancer stem cells. J Cell Sci 2013; 126: 4220-4229. https://doi.org/10.1242/jcs.127944

[63] YU D, SHIN H-S, LEE YS, LEE YC. miR-106b modulates cancer stem cell characteristics through TGF- $\beta /$ Smad signaling in CD44-positive gastric cancer cells. Lab Invest 2014; 94: 1370-1381. https://doi.org/10.1038/labinvest.2014.125 
[64] TAFT RJ, PANG KC, MERCER TR, DINGER M, MATTICK JS. Non-coding RNAs: regulators of disease. J Pathol 2010; 220: 126-139. https://doi.org/10.1002/path.2638

[65] HAO NB, HE YF, LI XQ, WANG K, WANG RL. The role of miRNA and lncRNA in gastric cancer. Oncotarget 2015; 8: 81572-81582. https://doi.org/10.18632/oncotarget.19197

[66] GUTSCHNER T, DIEDERICHS S. The hallmarks of cancer: a long non-coding RNA point of view. RNA Biol 2012; 9: 703-719. https://doi.org/10.4161/rna.20481

[67] SHI X, SUN M, LIU H, YAO Y, SONG Y. Long non-coding RNAs: A new frontier in the study of human diseases. Cancer Lett 2013; 339: 159-166. https://doi.org/10.1016/j.canlet.2013.06.013

[68] MERCER TR, DINGER ME, MATTICK JS. Long non-coding RNAs: insights into functions. Nature Rev Genet 2009; 10: 155-159. https://doi.org/10.1038/nrg2521

[69] CAI B, SONG XQ, CAI JP, ZHANG S. HOTAIR: a cancer-related long non-coding RNA. Neoplasma 2014; 61: 379-391. https://doi.org/10.4149/neo_2014_075

[70] OKUGAWA Y, TOIYAMA Y, HUR K, TODEN S, SAIGUSA $S$ et al. Metastasis-associated long non-coding RNA drives gastric cancer development and promotes peritoneal metastasis. Carcinogenesis 2014; 35: 2731-2739. https://doi. org/10.1093/carcin/bgu200

[71] YANG F, XUE X, ZHENG L, BI J, ZHOU Y et al. Long noncoding RNA GHET1 promotes gastric carcinoma cell proliferation by increasing c-Myc mRNA stability. FEBS J 2014; 281: 802-813. https://doi.org/10.1111/febs.12625

[72] XU TP, HUANG MD, XIA R, LIU XX, SUN M et al. Decreased expression of the long non-coding RNA FENDRR is associated with poor prognosis in gastric cancer and FENDRR regulates gastric cancer cell metastasis by affecting fibronectin1 expression. J Hematol Oncol 2014; 7: 63. https:// doi.org/10.1186/s13045-014-0063-7

[73] SUN M, XIA R, JIN F, XU T, LIU Z et al. Downregulated long noncoding RNA MEG3 is associated with poor prognosis and promotes cell proliferation in gastric cancer. Tumour Biol 2014; 35: 1065-1073. https://doi.org/10.1007/s13277013-1142-Z

[74] ARITA T, ICHIKAWA D, KONISHI H, KOMATSU S, SHIOZAKI A et al. Circulating long non-coding RNAs in plasma of patients with gastric cancer. Anticancer Res 2013; 33: 3185-3193.

[75] DONG L, QI P, XU MD, NI SJ, HUANG D et al. Circulating CUDR, LSINCT-5 and PTENP1 long noncoding RNAs in sera distinguish patients with gastric cancer from healthy controls. Int J Cancer 2015; 137: 1128-1135. https://doi. org/10.1002/ijc. 29484

[76] XIE S-S, JIN J, XU X, ZHUO W, ZHOU T-H. Emerging roles of non-coding RNAs in gastric cancer: Pathogenesis and clinical implications. World J Gastroenterol 2016; 22: 12131223. https://doi.org/10.3748/wjg.v22.i3.1213
[77] YAO Y, SUO A-L, LI ZF, YING L, TIAN T et al. MicroRNA profiling of human gastric cancer. Mol Med Rep 2009; 2: 963-970. https://doi.org/10.3892/mmr_00000199

[78] KATADA T, ISHIGURO H, KUWABARA Y, KIMURA M, MITUI A et al. microRNA expression profile in undifferentiated gastric cancer. Int J Oncol 2009; 34: 537-542. https:// doi.org/10.3892/ijo_00000179

[79] TCHERNITSA O, KASAJIMA A, SCH FER R, KUBAN RJ, UNGETH M U et al. Systematic evaluation of the miRNAome and its downstream effects on mRNA expression identifies gastric cancer progression. J Pathol 2010; 222: 310-319. https://doi.org/10.1002/path.2759

[80] LI X, ZHANG Y, ZHANG H, LIU X, GONG T et al. miRNA-223 Promotes Gastric Cancer Invasion and Metastasis by Targeting Tumor Suppressor EPB41L3. Mol Cancer Res 2011; 9: 824. https://doi.org/10.1158/1541-7786.MCR-100529

[81] KIM C, K KIM H, LUKE RETTIG R, KIM J, T LEE E et al. MiRNA signature associated with outcome of gastric cancer patients following chemotherapy. BMC Med Genomics 2011; 4: 79. https://doi.org/10.1186/1755-8794-4-79

[82] UEDA T, VOLINIA S, OKUMURA H, SHIMIZU M, TACCIOLI $\mathrm{C}$ et al. Relation between microRNA expression and progression and prognosis of gastric cancer: a microRNA expression analysis. Lancet Oncol 2010; 11: 136-146. https:// doi.org/10.1016/S1470-2045(09)70343-2

[83] ZHOU X, XIA Y, SU J, ZHANG G. Down-Regulation of miR141 Induced by Helicobacter Pylori Promotes the Invasion of Gastric Cancer by Targeting STAT4. Cell Physiol Biochem 2014; 33: 1003-1012. https://doi.org/10.1159/000358671

[84] LIU J, WANG X, YANG X, LIU Y, SHI Y et al. miRNA423$5 p$ regulates cell proliferation and invasion by targeting trefoil factor 1 in gastric cancer cells. Cancer Lett 2014; 347: 98-104. https://doi.org/10.1016/j.canlet.2014.01.024

[85] HAN X, CHEN Y, YAO N, LIU H, WANG Z. MicroRNA let$7 \mathrm{~b}$ suppresses human gastric cancer malignancy by targeting ING1. Cancer Gene Ther 2015; 22: 122-129. https://doi. org/10.1038/cgt.2014.75

[86] FAN D, REN B, YANG X, LIU J, ZHANG Z. Upregulation of miR-501-5p activates the wnt $/ \beta$-catenin signaling pathway and enhances stem cell-like phenotype in gastric cancer. J Exp Clin Cancer Res 2016; 35: 177. https://doi.org/10.1186/ s13046-016-0432-x

[87] JI Q, HAO X, MENG Y, ZHANG M, DESANO J et al. Restoration of tumor suppressor miR-34 inhibits human p53mutant gastric cancer tumorspheres. BMC Cancer 2008; 8: 266. https://doi.org/10.1186/1471-2407-8-266

[88] LIU J, MA L, WANG Z, WANG L, LIU C et al. MicroRNA expression profile of gastric cancer stem cells in the MKN-45 cancer cell line. Acta Biochim Biophys Sin (Shangai) 2014; 46: 92-99. https://doi.org/10.1093/abbs/gmt135 